\title{
How sensitive are Britain's inpayments and outpayments to the value of the British pound
}

\author{
Mohsen Bahmani-Oskooee, Claire Economidou and
}

Gour Gobinda Goswami

The Center for Research on International Economics and Department of

Economics, The University of Wisconsin-Milwankee, Milwankee,

Wisconsin, USA

\begin{abstract}
Purpose - To avoid aggregation bias by using trade data at bilateral level so that we can determine how sensitive are Britain's inpayments and outpayments to the value of the British pound.

Design/methodology/approach - The method is based on the bounds testing approach to cointegration and error-correction modeling.

Findings - The main finding is that while UK inpayments are not sensitive to the exchange rate, her outpayments are.

Research limitations/implications - Future research must concentrate on disaggregating data further, perhaps at commodity level.

Practical implications - The results could be used to identify Britain's trading partners against which Britain can devalue the pound and improve her trade balance.

Originality/value - No study has attempted to test the impact of real depreciation of the pound on Britain's payments and receipts with her major trading partners.
\end{abstract}

Keywords United Kingdom, Currency accounting, Trade balances, International trade,

Financial management

Paper type Research paper

\section{Introduction}

Standard text book argument pertaining to the relation between a small country's trade balance and her exchange rate is that devaluation will have a favorable impact on the trade balance as long as sum of the import and export demand elasticities add up to more than one. This elasticity condition is tested by estimating import and export demand equations in which trade volumes are regressed on the relative prices and some scale variables. From the estimate of import demand elasticity one concludes whether the product of import volume and import prices (i.e. a country's outpayments) declines due to devaluation. Similarly, from the estimate of export demand elasticity one deducts the direction in which the product of export volume and export prices (i.e. inpayments) will move[1].

One could raise two questions against the studies that have relied upon trade elasticities to infer the effectiveness of devaluation. First, the elasticity approach is an indirect method of assessing the effectiveness of devaluation. Why not rely upon models in which inpayments or outpayments are directly regressed on the exchange rate in addition to other determinants? The second concern relates to the fact that such elasticity estimates suffer from the aggregation bias, for they are obtained by using

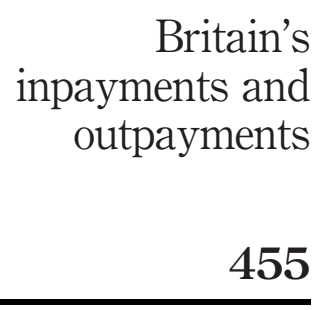


JES

32,6

456

aggregate trade data. Bahmani-Oskooee and Goswami (2004) have argued that it is possible that a significant price elasticity with one trading partner could be more than offset by an insignificant elasticity with another partner yielding an insignificant trade elasticity. To remedy these two problems, a new body of the literature has emerged. To avoid aggregation bias, recent studies employ trade data at bilateral level. However, due to lack of import and export prices, they establish a direct link between import or export values and the exchange rate, a rather direct method of assessing the relation between exchange rate and trade. The limited number of studies in this later group have concentrated their efforts on the analysis of bilateral trade between US and her major trading partners. The list includes Summary (1989), Marquez (1990), Eaton (1994), Haynes et al. (1996), Sukar and Zoubi (1996), Cushman (1987, 1990), Bahmani-Oskooee and Brooks (1999) and Nadenichek (2000)[2]. The main conclusion in most of these studies is that real exchange rate is a significant determinant of the US bilateral trade flows. Bahmani-Oskooee and Goswami (2004) is a recent addition to the literature who reach similar conclusion by investigating the bilateral trade flows (inpayments and outpayments) between Japan and her nine largest trading partners.

The main purpose of this paper is to extend the literature by considering the experience of United Kingdom. More precisely we estimate the bilateral trade flow equations between UK and her 20 trading partners, i.e. Australia, Austria, Canada, Denmark, Finland, France, Germany, Greece, India, Ireland, Italy, Japan, Netherlands, Norway, Singapore, South Africa, Spain, Sweden, Switzerland, and the US. Section 2 outlines bilateral trade flow models as well as the methodology. Section 3 presents the empirical results. Unlike the US experience, it appears that the exchange rate does not play any significant role in most cases. Section 4 concludes. Finally, data definition and sources are cited in the appendix.

\section{The models}

As indicated above, our purpose is to establish a direct link between the UK inpayments and the exchange value of the pound in one relation and between the UK outpayments and the exchange value of the pound in another relation, both at bilateral level. Following Cushman (1987, 1990), Haynes et al. (1996) and Bahmani-Oskooee and Goswami (2004), the following models are adopted. These models display the bilateral inpayments and outpayments models between UK and trading partner $i$.

$$
\begin{gathered}
\log \mathrm{VX}_{i t}=a+b \log Y_{i t}+c \log \left(\frac{P_{i} E_{i}}{P_{\mathrm{UK}}}\right)_{t}+\varepsilon_{t} \\
\log \mathrm{VM}_{i t}=d+e \log Y_{\mathrm{UK}, t}+f \log \left(\frac{P_{i} E_{i}}{P_{\mathrm{UK}}}\right)_{t}+\omega_{t}
\end{gathered}
$$

In equation (1) UK inpayments by country $i$ is measured by her export value denoted by $\mathrm{VX}_{i t}$. It is assumed that $\mathrm{VX}_{i}$ is positively related to country $i$ 's income $\left(Y_{i t}\right)$. Thus, we expect an estimate of $b$ to be positive indicating the fact that as $i$ 's income grows, she imports more from UK. It is also assumed that the real bilateral exchange rate between UK and trading partner $i$, i.e. $\left(P_{i} E_{i} / P_{\mathrm{UK}}\right)$ is another determinant of the UK inpayments. 
Note that in this setup $E_{i}$ is defined as number of pounds per unit of $i$ 's currency, $P_{i}$ is the price level in $i$ and $P_{\mathrm{UK}}$, the price level in UK Thus, an increase in real exchange rate reflects a real appreciation of $i$ 's currency or a real depreciation of the pound. If real depreciation of the pound is to increase UK,'s inpayments, an estimate of $c$ should be positive. Equation (2) outlines the determinants of the UK outpayments to country $i$. In equation (2), $\mathrm{VM}_{i t}$ denotes the value of imports by UK from trading partner $i$. It is assumed that it is positively related to the UK income denoted by $Y_{\mathrm{UK}}$ Finally, if real depreciation of the pound is expected to lower UK outpayments, an estimate of $f$ should be negative.

The two models outlined by equations (1) and (2) are long-run relationships among the trade values and their determinants. With existing literature on time-series modeling, in estimating equations (1) and (2) we must incorporate the short-run dynamics into our estimation procedure. This task is achieved by expressing both models in an error-correction modeling format. Following Engle and Granger (1987), the two error-correction models takes the following form:

$$
\begin{aligned}
\Delta \log \mathrm{VX}_{i t}= & a^{\prime}+\sum_{k=1}^{n 1} b_{k}^{\prime} \Delta \log \mathrm{VX}_{i t-k}+\sum_{k=0}^{n 2} c_{k}^{\prime} \Delta \log Y_{i t-k} \\
& +\sum_{k=0}^{n 3} d_{k}^{\prime} \Delta \log \left(\frac{P_{i} E_{i}}{P_{\mathrm{UK}}}\right)_{t-k}+e \varepsilon_{t-1}+\eta_{t} \\
\Delta \log \mathrm{VM}_{i t}= & e^{\prime}+\sum_{k=1}^{n 1} f_{k}^{\prime} \Delta \log \mathrm{VM}_{i t-k}+\sum_{k=0}^{n 2} g_{k}^{\prime} \Delta \log Y_{\mathrm{UK}, t-k} \\
& +\sum_{k=0}^{n 3} h_{k}^{\prime} \Delta \log \left(\frac{P_{i} E_{i}}{P_{\mathrm{UK}}}\right)_{t-k}+g \omega_{t-1}+\phi_{t}
\end{aligned}
$$

In equations (3) and (4), $\varepsilon_{t-1}$ and $\omega_{t-1}$ are lagged stationary residuals from equations (1) and (2), respectively. They only enter into error-correction models if variables in each of the models outlined by equations (1) and (2) are integrated of order one, hence I(1) but the residuals, i.e. $\varepsilon_{t}$ and $\omega_{t}$ are $\mathrm{I}(0)$. Therefore, Engle-Granger method consists of two steps. In the first step, one has to establish the I(1) property of each variable. In the second step, after applying the OLS on equations (1) and (2), one has to establish the $\mathrm{I}(0)$ property of the residuals. Note that cointegration could also be established if the lagged error correction terms, i.e. $\varepsilon_{t-1}$ and $\omega_{t-1}$ in equations (3) and (4) carry significantly negative coefficients. If cointegration is established, then the error-correction models are estimated. What to do if some variables are $\mathrm{I}(1)$ and some $\mathrm{I}(0)$ ?

Pesaran et al. (2001) offer a new method in which there is no need for pre-unit root testing. In equations (3) and (4) they substitute $\varepsilon_{t-1}$ and $\omega_{t-1}$ by linear combination of the lagged level of variables as in equations (5) and (6) below: 
JES

32,6

458

$$
\begin{aligned}
\Delta \log \mathrm{VX}_{i t}= & a^{\prime}+\sum_{k=1}^{n 1} b_{k}^{\prime} \Delta \log \mathrm{VX}_{i t-k}+\sum_{k=0}^{n 2} c_{k}^{\prime} \Delta \log Y_{i t-k}+\sum_{k=0}^{n 3} d_{k}^{\prime} \Delta \log \left(\frac{P_{i} E_{i}}{P_{\mathrm{UK}}}\right)_{t-k} \\
& +b \log \mathrm{VX}_{i t-1}+c \log Y_{i t-1}+d \log \left(\frac{P_{i} E_{i}}{P_{\mathrm{UK}}}\right)_{t-1}+\xi_{t}
\end{aligned}
$$

$$
\begin{aligned}
\Delta \log \mathrm{VM}_{i t}= & e^{\prime}+\sum_{k=1}^{n 1} f_{k}^{\prime} \Delta \log \mathrm{VM}_{i t-k}+\sum_{k=0}^{n 2} g_{k}^{\prime} \Delta \log Y_{\mathrm{UK}, t-k} \\
& +\sum_{k=0}^{n 3} h_{k}^{\prime} \Delta \log \left(\frac{P_{i} E_{i}}{P_{\mathrm{UK}}}\right)_{t-k}+f \log \mathrm{VM}_{i t-1}+g \log Y_{\mathrm{UK}, t-1} \\
& +h \log \left(\frac{P_{i} E_{i}}{P_{\mathrm{UK}}}\right)_{t-1}+v_{t}
\end{aligned}
$$

This new approach known as autoregressive distributed lag (ARDL) approach to cointegration provides a direct method of testing for cointegration. It amounts to testing whether the lagged level of variables (as a proxy for lagged error term) are jointly significant in each model. If they are jointly significant, they are said to be cointegrated. Thus, the null of no cointegration, i.e. $b=c=d=0$ in equation (5) and $f=g=h=0$ in equation (6) are tested against the alternative of $b \neq c \neq d \neq 0$ in equation (5) and $f \neq g \neq h \neq 0$ in equation (6) by using the familiar $F$-test with new critical values. Pesaran et al. (2001) tabulate new critical values irrespective of whether variables are integrated of order one or order zero. Note that in this setup, the short-run effects of depreciation is judged by the sign and size of $d_{k}^{\prime}$ 's in equation (5) and $h_{k}^{\prime}$ 's in equation (6) and the long-run effects by the size and sign of estimates obtained for $d$ and $h$ in equations (5) and (6), respectively (after normalization).

\section{Empirical results}

In this section, we try to estimate the error-correction models (5) and (6) between the UK and her 20 largest trading partners, i.e. Australia, Austria, Canada, Denmark, Finland, France, Germany, Greece, India, Ireland, Italy, Japan, Netherlands, Norway, Singapore, South Africa, Spain, Sweden, Switzerland, and the US using quarterly data over 1973I-2002IV period. In estimating any ARDL model, such as equations (5) or (6) Pesaran et al. (2001) propose two steps. In the first step, they propose imposing an arbitrary number of lags on the first differenced variables and applying the $F$-test to determine the cointegrating properties of the variables. Once cointegration (or lack thereof) is established, they suggest using a lag selection criterion to estimate the entire ARDL model. Bahmani-Oskooee and Brooks (1999) and Bahmani-Oskooee and Goswami (2004) have demonstrated that the $F$-test results in the first step are sensitive to the number of lags imposed on each first differenced variable. To avoid this problem, in this paper, we combine Pesaran et al.'s two steps into one. We estimate equations (5) and (6) using Akike information criterion (AIC) for selecting the optimum number of lags. Once optimum numbers of lags are determined, we carry out the $F$-test for joint significance of the lagged level variables or for cointegration. Table I reports the results for both models. 


\begin{tabular}{|c|c|c|c|c|c|}
\hline \multirow[b]{2}{*}{$\begin{array}{l}\text { Partner } \\
\text { country }\end{array}$} & \multicolumn{2}{|c|}{ Outpayments (imports) } & \multicolumn{2}{|c|}{ Inpayments (exports) } & \multirow{2}{*}{$\begin{array}{r}\text { Britain's } \\
\text { inpayments and } \\
\text { outpayments }\end{array}$} \\
\hline & $\begin{array}{l}\text { Optimum number of } \\
\text { lags }\end{array}$ & $\begin{array}{l}\text { Value of } F \\
\text { statistics }\end{array}$ & $\begin{array}{l}\text { Optimum number of } \\
\text { lags }\end{array}$ & $\begin{array}{l}\text { Value of } F \\
\text { statistics }\end{array}$ & \\
\hline Australia & $3,6,8$ & 4.874 & $1,0,2$ & 8.655 & \\
\hline Austria & $4,0,0$ & 7.493 & $2,0,3$ & 5.258 & \\
\hline Canada & $10,0,3$ & 6.661 & $4,0,0$ & 7.698 & 459 \\
\hline Denmark & $7,0,1$ & 2.842 & $9,0,0$ & 5.966 & \\
\hline Finland & $2,0,0$ & 4.793 & $4,0,1$ & 1.324 & \\
\hline France & $8,0,0$ & 3.818 & $12,0,0$ & 3.884 & \\
\hline Germany & $6,4,1$ & 2.022 & $4,4,10$ & 3.812 & \\
\hline Greece & $4,0,0$ & 2.758 & $7,5,0$ & 1.891 & \\
\hline India & $3,7,0$ & 2.718 & $3,1,0$ & 3.063 & \\
\hline Ireland & $8,0,0$ & 3.366 & $8,5,0$ & 7.496 & \\
\hline Italy & $8,0,0$ & 5.227 & $12,0,6$ & 6.395 & \\
\hline Japan & $4,0,2$ & 2.730 & $5,3,2$ & 3.917 & \\
\hline Netherlands & $1,0,0$ & 7.457 & $5,0,0$ & 2.790 & \\
\hline Norway & $11,11,10$ & 4.240 & $1,4,0$ & 3.266 & \\
\hline Singapore & $2,4,0$ & 2.610 & $4,0,0$ & 5.365 & \\
\hline South Africa & $8,11,1$ & 2.734 & $8,3,2$ & 0.635 & \\
\hline Spain & $12,4,2$ & 4.236 & $6,0,0$ & 2.145 & \\
\hline Sweden & $2,1,0$ & 1.472 & $7,2,1$ & 2.395 & \\
\hline Switzerland & $4,7,12$ & 2.785 & $3,1,1$ & 2.150 & \\
\hline US & $12,1,4$ & 7.592 & $9,0,3$ & 4.880 & \\
\hline \multicolumn{5}{|c|}{$\begin{array}{l}\text { Notes: The first lag is for } \Delta \mathrm{LVX} \text { or } \Delta \mathrm{LVM} \text {, the second is for } \Delta \mathrm{LYP} \text { or } \Delta \mathrm{LYF} \text {, and the last one is for } \\
\Delta \mathrm{LREX} \text {; the critical value of } F \text {-statistic for cointegration is } 3.80 \text {; trade flows are measured in terms of } \\
\text { trading partner's currency }\end{array}$} & $\begin{array}{r}\text { The } F \text {-test for } \\
\text { cointegration (lag length } \\
\text { selected by AIC) }\end{array}$ \\
\hline
\end{tabular}

The results in Table I show that in each model the calculated $F$-statistic is higher than the critical value in almost 50 percent of the cases. It worth noting that most of these significant cases includes countries that are large trading partners of the UK, for example, cointegration is confirmed in both models between UK and the US, Canada, France and Australia. To proceed with the analysis, we will assume cointegration among the variables so that we can retain the lagged level variables. This assumption is mostly based on more powerful results in support of cointegration (via error-correction term) to be presented.

Although the lag lengths in each case are shown in Table I, in order to have a better understanding of the short-run dynamics we need to report the full-information results. However, due to large volume of output and for brevity of presentation we only report the long-run coefficient estimates. For the short-run coefficient estimates, i.e. estimates obtained for the lagged first differenced variables, all we can say is that there was no specific pattern such as J-curve[3]. The long-run coefficient estimates after being normalized by the estimate of $b$ in equation (5) and $f$ in equation (6) are shown in Table II.

Panel A in Table II shows the results for import demand function and Panel B for export demand function. From Panel A, we gather that the real exchange rate carries its expected negative sign and it is significant in 13 out of 20 cases indicating that real depreciation of British pound decreases UK outpayments. However, from Panel B it is clear that real depreciation of the pound has either no significant effect on UK 
JES
32,6

460

Table II.

Long-run coefficient estimates (trade flows measured in trading partner's currency)

\begin{tabular}{|c|c|c|c|c|c|c|c|}
\hline \multirow[b]{2}{*}{ Partner country } & \multicolumn{3}{|c|}{ Coefficient estimates of } & \multicolumn{3}{|c|}{ Diagnostic test results } & \multirow[b]{2}{*}{$E C_{t-1}$} \\
\hline & Constant & & $\log P_{i} E_{i} / P_{\mathrm{UK}}$ & & & & \\
\hline \multicolumn{8}{|c|}{ Panel A: import demand equation for the UK } \\
\hline & $-11.98(5.64)$ & $3.80(7.19)$ & $-1.36(3.49)$ & 0.44 & 1.64 & 0.69 & $-0.52(4.16)$ \\
\hline & & & & & & & \\
\hline & $-0.60(0.50)$ & & & & 3.19 & 3.10 & $45(4.77)$ \\
\hline & & & & 0.27 & 1.72 & 0.10 & \\
\hline & $-8.90(4.83)$ & & $-0.94(3.07)$ & 0.25 & 3.29 & 10.41 & $24(4.19)$ \\
\hline & & & & & 2.39 & 0.16 & $0.17(3.83)$ \\
\hline & & & & & 7.68 & & \\
\hline & & & & & 4.69 & & \\
\hline & & & & & 3.27 & & \\
\hline & $-12.38(3$ & & & & 3.47 & 2.8 & 2.85) \\
\hline & & & & & 2.74 & & \\
\hline & & & & & & & \\
\hline & & & & & & & \\
\hline & -12 & & & & 6.25 & 2. & \\
\hline & -22 & & & & 0.19 & 14.54 & $24(3.13)$ \\
\hline & & & & & 9.77 & & \\
\hline & & & & & 22 & 0. & \\
\hline & & & & & 3.33 & 3.82 & 2.62) \\
\hline land & & & -0.06 & & 6.16 & 1.15 & (2.91) \\
\hline & $-12.62(8.46)$ & 4.65 (14.01) & $0.15(0.41)$ & 0 & 3.99 & 0.31 & \\
\hline \multicolumn{8}{|c|}{ Panel B: export demand equation for the UK } \\
\hline & & & $-0.25(1.53)$ & & & 13.28 & \\
\hline & & & & & 2.63 & 8.20 & $4(5.08)$ \\
\hline & -8.2 & & -0 & & 4.45 & 0.34 & $3(4.30)$ \\
\hline & & & & & & & \\
\hline & & & & & 0.31 & 0.37 & \\
\hline & & -0.8 & -2.60 & & 4.62 & 0.68 & $.09(3.24$ \\
\hline & & & -0 & & 1.40 & 0.60 & $08(1.51$ \\
\hline & & $-94.88(0.32)$ & -39 & & 5.49 & 2.87 & $1(0.38$ \\
\hline & & & & & 0.92 & 11.45 & \\
\hline & & & -2 & & 3.76 & 0. & -1 \\
\hline & & & & & 1.35 & 0.3 & $.10(2.97$ \\
\hline & & & & & 4.49 & 1.25 & -0.08 \\
\hline & & & & & 1.43 & 2.31 & \\
\hline & & & & & 3.27 & & \\
\hline & & & -0.2 & & 5.68 & & $31(3.21$ \\
\hline South Africa & $-53.13(1.06)$ & 13.07 (1.08) & $-1.92(0.51)$ & 0.37 & 8.44 & 9.72 & $-0.03(0.86$ \\
\hline & $-1.69(0.08)$ & $200-1$ & $1.71(0.57)$ & 0.37 & 2.26 & 0.63 & -0.04 \\
\hline & & $-0.34(0$. & $-1.77(1$ & 0.4 & 6.61 & 4.68 & \\
\hline & $-1.77(0.27)$ & & & 0.28 & 8.01 & 2.14 & -0.09 \\
\hline & $-1.61(0.97)$ & $2.28(6.36)$ & $0.46(0.74)$ & 0.53 & 3.40 & 1.64 & -0.16 \\
\hline
\end{tabular}

Notes: Figures in the parentheses represent the absolute values of the (asymptotic) $t$-ratios; trade flows are measured in terms of trading partner's currency

inpayments or even adverse effect in a few cases. The income variables in both panels carry their expected signs and are highly significant in almost all cases.

Table II also shows some diagnostic statistics. First, using the long-run coefficient estimates we calculate the linear combination of lagged level variables in each model and 
denote it by $\mathrm{EC}_{t-1}$. After imposing the optimum number of lags on each first differenced variable, we estimate the models by including $\mathrm{EC}_{t-1}$ as lagged error-correction term rather than the linear combination of lagged level variables. A negative and significant coefficient obtained for $\mathrm{EC}_{t-1}$ is another and relatively more powerful way of establishing cointegration (Bahmani-Oskooee and Brooks, 1999). As can be seen in both panels and in almost all cases, $\mathrm{EC}_{t-1}$ carries a negative and significant coefficient, justifying retention of lagged level variables in specifications (5) and (6). Furthermore, shown in Table II are the Lagrange multiplier (LM) statistic for residual serial correlation and Ramsey's RESET statistic for misspecification. Both statistics are distributed as $\chi^{2}$ with four and one degrees of freedom, respectively. It is clear that our models pass these tests in majority of the cases. Finally, to ensure that estimated coefficients are stable over time, following Bahmani-Oskooee and Kara (2003), we apply the CUSUM and CUSUMSQ tests to the residuals of error-correction models (5) and (6). The CUSUM and CUSUMSQ statistics are updated recursively and plotted against break points. For stability of all coefficients, the plot of these two statistics must stay within 5 percent significance level (portrayed by two straight lines whose equations are given in Brown et al. (1975, Section 2.3)). For demonstrative purpose we show the results for the case of UK vs US in Figure 1.

Since the plot of CUSUM and CUSUMSQ statistics do stay within the critical lines, the estimated coefficients are indeed stable. The results for remaining countries are summarized in Table III.

As can be seen, at least CUSUM test supports stability of estimated coefficients in almost all cases.

So far export and import values were measured in terms of trading partner's (foreign) currency. In order to assess the sensitivity of the results to choice of currency in which import and export values are denominated, we first measure the trade flows in terms of domestic currency (i.e. British Pound) and then in terms of a reserve currency (US Dollar). Once again since there was no specific short-run pattern, we restrict ourselves to reporting the long-run results. Tables IV and V show these results.

From Tables IV and V, we gather that only in the import demand estimates (Panel A of Table IV) number of significant coefficient attached to real exchange rate drops from 13 to 7 . The remaining features of both tables are similar to the results shown in Table II. We may then conclude that real depreciation of the British pound lowers UK outpayments and has no significant impact on her inpayments, supporting the notion that currency depreciation will have favorable effect on UK trade balance.

\section{Summary and conclusion}

Currency depreciation is said to improve a country's trade balance if it lowers her outpayments and increases her inpayments. Most previous studies estimated trade flow equations to determine whether price elasticities in the import and export demand functions add up to more than unity, a condition known as the Marshall-Lerner condition which is said to be an indirect method of analyzing the effectiveness of depreciation. A direct way would be to relate a country's inpayments (export value) and outpayments (import value) to the exchange rate in addition to other determinants.

In this paper, we first outline the long-run relationships between the UK's inpayments and real value of the pound in one relation and between the UK's outpayments and the real value of the pound in another relationship. The models then are expressed in an 
JES

32,6

\section{2}

Panel A: Out payments (VM)

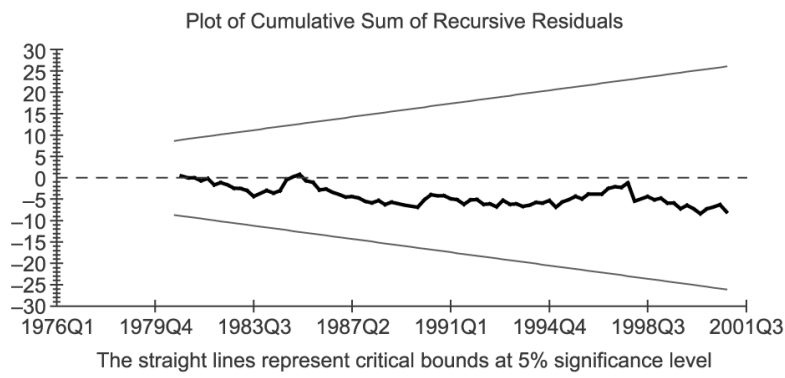

Plot of Cumulative Sum of Squares of Recursive Residuals

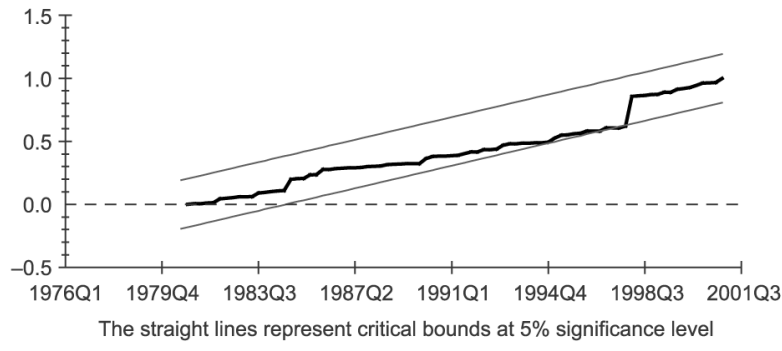

Panel B: Out payments (VX)

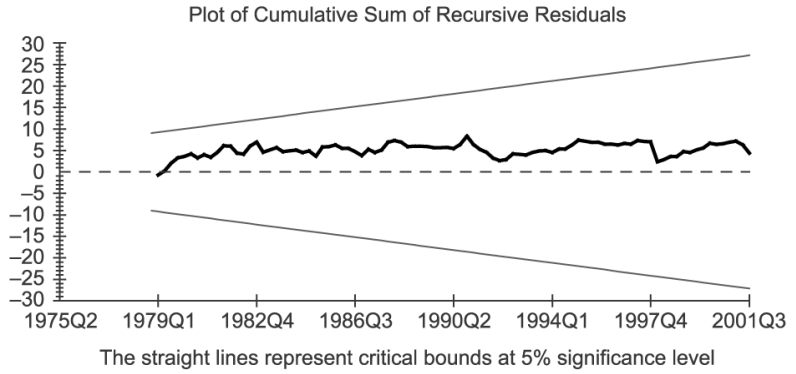

Plot of Cumulative Sum of Squares of Recursive Residuals

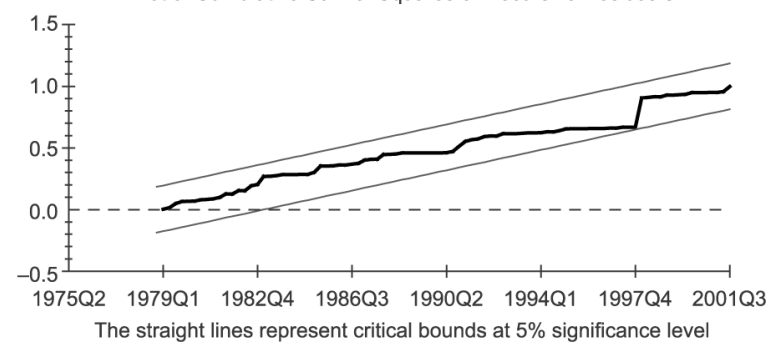

Figure 1.

Stability test results for the UK vis-à-vis US 


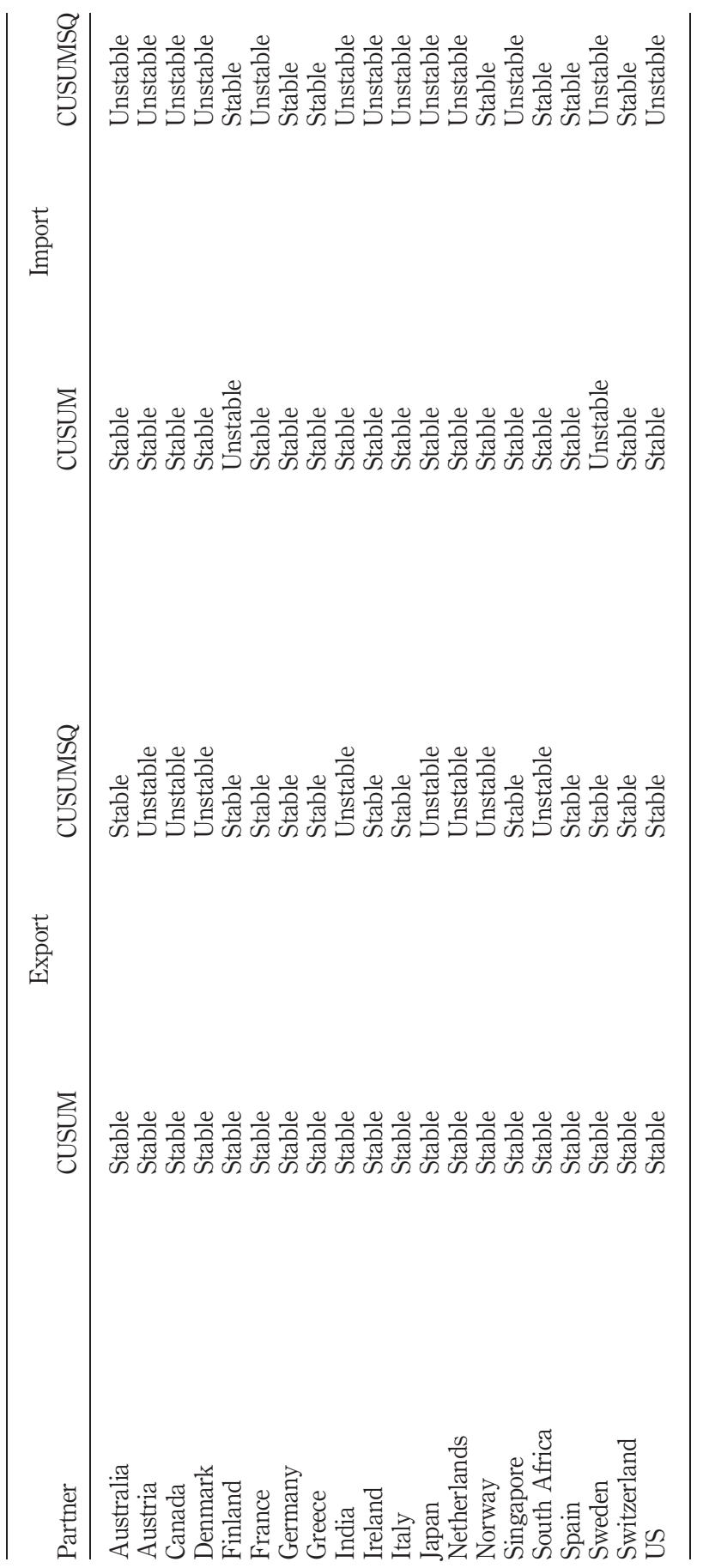

Britain's inpayments and outpayments

463

Table III.

Stability test results for all trading partners 
JES
32,6

464

\begin{tabular}{|c|c|c|c|c|c|c|c|}
\hline \multirow[b]{2}{*}{ Partner country } & \multicolumn{3}{|c|}{ Coefficient estimates of } & \multicolumn{3}{|c|}{ Diagnostic test results } & \multirow[b]{2}{*}{$\mathrm{EC}_{\mathrm{t}-1}$} \\
\hline & Constant & $\log Y_{\mathrm{UK}}$ & $\log P_{i} E_{i} / P_{\mathrm{UK}}$ & Adj $R^{2}$ & LM & RESET & \\
\hline \multicolumn{8}{|c|}{ Panel A: import demand equation } \\
\hline A uctralia & $-11.30(5.08)$ & $3.64(6.56)$ & $-0.45(1.10)$ & 0.44 & 1.92 & 1.14 & $-0.52(4.2$ \\
\hline & 16.19 (8.99) & 4.69 (11.72) & $-1.31(3.16)$ & & & & \\
\hline & $-2.24(1.63)$ & $88(5.72)$ & $0.13(0.53)$ & 0.44 & 5.44 & 1.07 & 0 \\
\hline & $-6.42(2.70)$ & $2.33(4.54)$ & $-0.93(2.05)$ & 0.24 & 4.47 & 0.35 & $-0.19(3.1$ \\
\hline & $-10.32(4.89)$ & & & & 5.72 & & $-0.21(3.4$ \\
\hline & $10.27(4.42)$ & & & & & & \\
\hline & & & -1.2 & & & & \\
\hline & & & $-1.52(2.29)$ & & & & \\
\hline & $-22.94(3.81)$ & & & & 2.60 & 1. & \\
\hline & & & -0.99 & & & & \\
\hline & & & & & & & \\
\hline & & -1.9 & & & & 2. & \\
\hline rlands & $-8.29(3.6$ & & $-1.08(2.55)$ & & 4.93 & 3.01 & $(3.8$ \\
\hline & $-13.54(4.1$ & & $-4.01(3.68)$ & & 5.34 & 2.77 & \\
\hline & & & & & & & \\
\hline & & & & & & & \\
\hline & & & -0.1 & & & & $-0.11(2.4$ \\
\hline & & & & & & 4.32 & \\
\hline & & & & & & & \\
\hline \multirow{2}{*}{\multicolumn{8}{|c|}{ Panel B: export demand equation }} \\
\hline & & & & & & & \\
\hline Australia & $-4.74(7.35)$ & & $0.47(2.71)$ & 0.18 & 12.68 & 21.43 & $-0.65(7.17$ \\
\hline & & & & & & & \\
\hline & -1 & & & & & & \\
\hline & & & $-0.18(0.57)$ & & 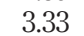 & & \\
\hline & -1.68( & & & & & & $3(1.9$ \\
\hline & & & & & & 0.13 & $9(3.3$ \\
\hline & -1 & & & & & & \\
\hline & & 11 & & & & & \\
\hline & & & $0.77(1.15)$ & & 2.92 & 9.4 & $21(3.1$ \\
\hline & & & $-1.08(2.90)$ & & 0.96 & 0.01 & $26(3.9$ \\
\hline & -1.73 & & & & & & \\
\hline & & & & & & 0.0 & \\
\hline & -0.13 & & $-0.16(0$. & & & 1. & \\
\hline & & & $-0.14(0.19)$ & & & 2.31 & $32(3.8$ \\
\hline Singapore & $1.08(1.26)$ & $1.23(7.47)$ & $0.62(1.11)$ & 0.33 & 8.24 & 0.98 & $-0.15(2.3$ \\
\hline South Africa & $-7.80(1.25)$ & & $-0.09(0.08)$ & 0.2 & 6.33 & 16.16 & \\
\hline & $-11.93(1.46)$ & & & & 2.21 & 0.01 & \\
\hline & & & $-0.08(0.10)$ & & 3.74 & 8.61 & $-0.14(2.6$ \\
\hline Switzerland & $-4.63(1.77)$ & $2.60(4.34)$ & $0.81(0.88)$ & 0.27 & 5.03 & 5.90 & $-0.20(2.5$ \\
\hline & $-1.61(0.97)$ & $2.28(6.36)$ & $0.46(0.74)$ & 0.53 & 3.40 & 1.64 & -0.16 \\
\hline
\end{tabular}

Table IV.

Long-run coefficient estimates (trade flows measured in pound)
Note: Figures in the parentheses represent the absolute values of the (asymptotic) $t$-ratios

error-correcting modeling format and estimated between UK and her 20 trading partners that include Australia, Austria, Canada, Denmark, Finland, France, Germany, Greece, India, Ireland, Italy, Japan, Netherlands, Norway, Singapore, South Africa, Spain, Sweden, Switzerland and the US. The empirical results showed that regardless of currency denomination, UK inpayments are not sensitive to real exchange rate changes. 


\begin{tabular}{|c|c|c|c|c|c|c|c|}
\hline \multirow[b]{2}{*}{ Partner country } & \multicolumn{3}{|c|}{ Coefficient estimates of } & \multicolumn{3}{|c|}{ Diagnostic test results } & \multirow[b]{2}{*}{$\mathrm{EC}_{t-1}$} \\
\hline & Constant & $\log Y_{\mathrm{UK}}$ & $\log P_{i} E_{i} / P_{\mathrm{UK}}$ & & LM & RESET & \\
\hline \multicolumn{8}{|c|}{ Panel A: import demand equation } \\
\hline & $-8.97(11.29)$ & $3.25(16.39)$ & $-0.34(2.34)$ & 0.44 & 5.96 & 0.44 & $-1.03(7.48)$ \\
\hline ustria & $-13.33(9.24)$ & & & 0.38 & 3.33 & 0.18 & \\
\hline anada & 1.35 (1.05) & $.70)$ & -0.16 & 0.42 & 1.27 & 1.44 & $0.42(4.75)$ \\
\hline enmark & $-4.57(2.17)$ & 2.38 & $-0.22(0.46)$ & 0.22 & 0.43 & 1.98 & \\
\hline nland & $-8.61(5.87)$ & $3.35(10.00)$ & & 0.35 & 2.41 & 7.18 & $-0.25(4.35)$ \\
\hline 20 & $-6.44(1.26)$ & $3.35(2.96)$ & & 0.32 & 3.11 & 0.00 & $-0.16(3.69)$ \\
\hline & 710 (100) & $3.50(4.34)$ & $-0.33(0.47)$ & 0.21 & 2.55 & 1.90 & $-0.09(2.67)$ \\
\hline & $-5.28(3$ & & -1.73 & & 18.19 & 2.81 & \\
\hline & -21.9 & & & 0.33 & 2.61 & 0.96 & \\
\hline & $-12.58(7.21)$ & 4.45( & $-0.06(0.11)$ & & 0.85 & 3.32 & $-0.32(4.87)$ \\
\hline & & & & & 4.89 & & \\
\hline & & -0.6 & & & & & \\
\hline & & & -1 & & & 0 . & \\
\hline & $-11.87(3$ & & -3.56 & 0. & 4.67 & 2.75 & \\
\hline & $-26.93(5$ & & -0.35 & 0.2 & 0.08 & 13.73 & $-0.18(2.63)$ \\
\hline & $-166.48(0$ & & & & & & \\
\hline & & & & & & & \\
\hline & $-1.50(2$ & & & & 2.96 & 3.85 & $-0.17(2.35)$ \\
\hline Switzerland & $-2.69(0.87)$ & & 1.47 & 0.4 & 4.51 & 2.39 & $-0.23(2.63)$ \\
\hline US & $-10.11(6.84)$ & 4.07 (11.51) & $-1.04(2.00)$ & 0.4 & 9.78 & 0.06 & $-0.25(5.54)$ \\
\hline \multicolumn{8}{|c|}{ Panel B: export demand equation for the UK } \\
\hline & $-2.41(1.14)$ & & & & 0.76 & 1.96 & \\
\hline & & & & & & & \\
\hline & -7.0 & & & 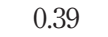 & 3.54 & 2.34 & $35(4.69)$ \\
\hline & & & & & & & \\
\hline & -1 & & & & 0.51 & 1.71 & \\
\hline & -3.3 & & & & 3.31 & 2.67 & $-0.06(2.09)$ \\
\hline & $-0.08(0.0$ & & & & 1.99 & 0.64 & $-0.05(1.36)$ \\
\hline & & -395601 & & & 1.41 & & $-0.05(1.04)$ \\
\hline & & & & & 0.62 & & \\
\hline & & & -0.6 & 0.5 & 1.04 & 0.28 & 0 (3.22) \\
\hline & & & $5.25(1.02)$ & 0.6 & 0.87 & 1.40 & $-0.13(2.97)$ \\
\hline & & & & 0.40 & 8.33 & 5.87 & $-0.06(1.24)$ \\
\hline & & & & & 3.63 & 8.30 & \\
\hline & & & -0.4 & & 2.4 & 3.4 & $-0.28(3$ \\
\hline & & & $-0.38(0.22)$ & & 5.03 & 0.22 & $16(2.30)$ \\
\hline South Africa & $0.20(0.04)$ & $0.98(0.69)$ & $-0.83(0.74)$ & 0.23 & 8.36 & 13.60 & $-0.18(2.42)$ \\
\hline Spain & $-13.04(1.54)$ & $4.82(2.67)$ & $4.50(1.62)$ & 0.49 & 2.03 & 0.07 & $-0.07(2.04)$ \\
\hline & & & & 0.5 & 4.17 & 2.55 & \\
\hline & & & & 0.2 & 6.52 & 2.02 & $-0.11(1.56)$ \\
\hline & $-1.44(1.07)$ & $2.19(7.19)$ & 0.98 (1.75) & 0.44 & 2.06 & 0.01 & $-0.17(4.09)$ \\
\hline
\end{tabular}

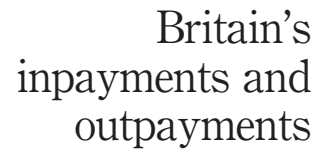

\section{outpayments}

Note: Figures in the parentheses represent the absolute values of the (asymptotic) $t$-ratios

Table V. Long-run coefficient estimates (trade flows measured in us dollar)

However, in many cases when outpayments were measured in terms of foreign currency, real depreciation of the pound was found to lower the outpayments. These findings are similar to those found for Japan by Bahmani-Oskooee and Goswami (2004). The fact that exports are not sensitive to exchange rate changes may reflect actions taken by British exporters to offset effects of exchange rate changes by adjusting their profit margin. 
JES

32,6

466

\section{Notes}

1. Example of studies that provided estimates of trade elasticities are: Kreinin (1967), Houthakker and Magee (1969), Goldstein and Khan (1976, 1978), Wilson and Takacs (1979), Haynes and Stone (1983a, b), Warner and Kreinin (1983), Bahmani-Oskooee $(1986,1998)$ and Bahmani-Oskooee and Niroomand (1998).

2. The exception is Summary (1989) who adhered to cross-sectional data from 66 US trading partners. However, she excluded prices and exchange rates from her model due to absence of data and "potential causation problem".

3. The short-run results are available from the authors upon request.

\section{References}

Bahmani-Oskooee, M. (1986), "Determinants of international trade flows: the case of developing countries", Journal of Development Economics, Vol. 20, pp. 107-23.

Bahmani-Oskooee, M. (1998), "Cointegration approach to estimate the long-run trade elasticities in LDCs", International Economic Journal, Vol. 12, pp. 89-96.

Bahmani-Oskooee, M. and Brooks, T.J. (1999), "Bilateral J-curve between US and her trading partners”, Weltwirtschaftliches Archiv, Vol. 135, pp. 56-165.

Bahmani-Oskooee, M. and Goswami, G. (2004), "Exchange rate sensitivity of Japan's bilateral trade flows", Japan and the World Economy, Vol. 16, pp. 1-15.

Bahmani-Oskooee, M. and Kara, O. (2003), "Relative responsiveness of trade flows to a change in prices and exchange rate", International Review of Applied Economics, Vol. 17, pp. 293-308.

Bahmani-Oskooee, M. and Niroomand, F. (1998), "Long-run price elasticities and the Marshall-Lerner condition revisited”, Economics Letters, Vol. 61, pp. 101-9.

Brown, R.L., Durbin, J. and Evans, J.M. (1975), "Techniques for testing the constancy of regression relations over time", Journal of the Royal Statistical Society, Series B, Vol. 37, pp. 149-92.

Cushman, D.O. (1987), "US bilateral trade balances and the dollar", Economics Letters, Vol. 24, pp. 363-7.

Cushman, D.O. (1990), "US bilateral trade equations: forecasts and structural stability", Applied Economics, Vol. 22, pp. 1093-102.

Eaton, J. (1994), "Bilateralism and regionalism in Japanese and US trade and direct foreign investment patterns", Journal of the Japanese and International Economies, Vol. 8, pp. 478-510.

Engle, R.F. and Granger, C.W.J. (1987), "Cointegration and error-correction: representation, estimation, and testing", Econometrica, Vol. 55, pp. 251-76.

Goldstein, M. and Khan, M. (1976), "Large versus small price changes and the demand for imports”, IMF Staff Papers, Vol. 23, pp. 200-25.

Goldstein, M. and Khan, M. (1978), "The supply and demand for exports: a simultaneous approach", Review of Economics and Statistics, Vol. 60, pp. 275-86.

Haynes, S.E. and Stone, J.A. (1983a), "Secular and cyclical responses of US trade to income: an evaluation of traditional models", Review of Economics and Statistics, Vol. 65, pp. 87-95.

Haynes, S.E. and Stone, J.A. (1983b), "Specification of supply behavior in international trade", Review of Economics and Statistics, Vol. 65, pp. 626-32.

Haynes, S.E., Hutchison, M.M. and Mikesell, R.F. (1996), "US-Japanese bilateral trade and the yen-dollar exchange rate: an empirical analysis", Southern Economic Journal, Vol. 52, pp. 923-32. 
Houthakker, H.S. and Magee, T.P. (1969), "Income and price elasticities in world trade", Review of Economics and Statistics, Vol. 51, pp. 111-25.

Kreinin, M.E. (1967), "Price elasticities in the international trade", The Review of Economics and Statistics, Vol. 49, pp. 510-6.

Marquez, J. (1990), "Bilateral trade elasticities", The Review of Economics and Statistics, Vol. 75, pp. $70-7$.

Nadenichek, J. (2000), "The Japan-US trade imbalance: a real business cycle perspective", Japan and the World Economy, Vol. 12, pp. 255-71.

Pesaran, H.M., Shin, Y. and Smith, R.J. (2001), "Bounds testing approach to the analysis of level relationships", Journal of Applied Econometrics, Vol. 16, pp. 289-326.

Sukar, A. and Zoubi, T. (1996), "Real exchange rates and US bilateral trade", Journal of Applied Business Research, Vol. 12, pp. 138-44.

Summary, R.M. (1989), "A political-economic model of US bilateral trade", The Review of Economics and Statistics, Vol. 71, pp. 179-82.

Warner, D. and Kreinin, M.E. (1983), "Determinants of international trade flows", Review of Economics and Statistics, Vol. 65, pp. 96-104.

Wilson, J.F. and Takacs, W.E. (1979), "Differential responses to price and exchange rate influences in the foreign trade of selected industrial countries", Review of Economics and Statistics, Vol. 61, pp. 267-79.

\section{Appendix. Data definition and sources}

Sources of the data

For all countries quarterly data over 1973Q1-2001Q3 period come from the following sources.

The data for:

(1) bilateral trade flow are taken from the direction of trade statistics of the IMF, various issues;

(2) industrial production index used as a proxy for real GDP, domestic and foreign CPI are taken from the International Financial Statistics of the IMF (CD-ROM); and

(3) bilateral nominal exchange rates are taken from National Accounts, OECD, CD-ROM, 2002. This data set converts all the previous currencies into their EURO equivalent (where applicable).

\section{Variables}

$\mathrm{VX}_{i} \quad$ UK's export value to trading partner $i$. The data come from source (1).

$\mathrm{VM}_{i} \quad$ UK's import value from trading partner $i$. The data come from source (1).

$Y \quad$ index of industrial production used as a proxy for real GDP, source (2).

$P \quad$ price level proxied by the CPI which comes from source (2).

NEX nominal exchange rate (period average). It is defined as the number of pounds per unit of trading partner's currency. The data come from source (3). 